\title{
Medical Emergency and Public Health Response in Disaster Settings: A Case Series of Pidie Jaya, Lombok and Palu Earthquakes
}

\author{
Safrizal Rahman ${ }^{1}$, Muhammad Bayu Zohari Hutagalung ${ }^{2}$ \\ ${ }_{1,2}$ Department of Surgery, Faculty of Medicine, Syiah Kuala University/Dr. Zainoel Abidin Hospital, Banda \\ Aceh, Indonesia \\ rizal.rhmn@gmail.com
}

\begin{abstract}
Indonesia is one of the most disaster-prone countries, often regarded as a "world disaster laboratory." Natural disasters cause destruction and human suffering, especially in low- and middle-income countries Objective: This paper presents the overview of a medical emergency and public health response towards several recent earthquakes in Pidie Jaya, Lombok, and Palu of Indonesia. Case Series: The authors examine the appropriateness and effectiveness of the organized disaster response of the Pidie Jaya, Lombok, and Palu earthquakes in medical emergency response. Pidie Jaya Earthquake: A 6.4 magnitude earthquake struck off Pidie Jaya Regency, province of Aceh in Sumatra Island, Indonesia, resulting in 104 people died and others 395 injured. Lombok Earthquake: A series of moderate and strong earthquakes have rocked cities and regencies in Lombok Island, West Nusa Tenggara (NTB) causing 436 people died, 783 people with severe injury and 570 people with a mild injury. Palu Earthquake: The 7.7 magnitude earthquake hit Donggala district and also affected Palu city and Parigi Mountong regency causing 2657 people died, 4471 people with severe injury and 87,835 people with a mild injury. Important Findings: Though Indonesia has made outstanding progress in disaster management, the country still has many challenges and problems to overcome. The integration of data and information about health needs the progress of relief work, and about various other problems related to health is one of the most urgent and vital for better improving the medical emergency response and public healthrelated support in disaster settings
\end{abstract}

Keywords: medical emergency; public health; disaster settings

\section{Introduction}

Agricultural land is increasingly narrow due to the shifting of the function of Indonesia, as the largest archipelago country in the world, is one of the most disaster-prone countries in the world. The deadliest disaster occurred in the early 21 st Century also happened in Indonesia. On 26 December 2004, a big earthquake struck in the sea near Simeuleu Island, west of Sumatra Island. The earthquake triggered a tsunami that later killed more than 225,000 people in eleven countries and devastated coastal areas in the countries it affected. (BNPN, 2009) In recent years, several major earthquake disasters happen in Indonesia, namely, Pidie Jaya-Aceh, Lombok-West Nusa Tenggara, and Palu-Central Sulawesi Earthquake. Though Indonesia has made outstanding progress in the last years building more resilience and working towards a nation where disaster risk reduction is the central point if attention the country still having many challenges and problems to overcome. One of the most urgent and vital is medical emergency response and public health-related support in disaster settings. (De Priester, 2016)

According to Ricardian in Adinew (2019), the projected result of current and future agricultural production as a function of temperature and precipitation over a 50 year period decline in agricultural productivity and this projection of climate change accounted for 30 percent less average income when compared with the absence of climate change.This paper presents the overview of a medical emergency and public health response towards several recent earthquakes in Pidie Jaya, Lombok, and Palu of Indonesia. 


\section{Review of Literature}

\subsection{Case Series}

The authors examine the appropriateness and effectiveness of the organized disaster response of the Pidie Jaya, Lombok, and Palu earthquakes in medical emergency response. Based on a study by Kuni O et al (1995), there is three vital questions which were designated as a research point in this study. The questions are:

1. What was responsible for the failure of Indonesia disaster planners to anticipate and prepare for an earthquake of this magnitude, given the vulnerability of the region to such incidents?

2. How could a more useful set of response plans have reduced mortality from each earthquake?

3. What could more appropriate medical and public health interventions have been provided for the injured and evacuees?

The authors highlight the similarity and difference of medical emergency and public health response in each disaster settings and elaborated into "lesson learned points" which hopefully became the critical aspects for improving health cluster response in disaster setting in Indonesia.

\subsection{Pidie Jaya Earthquake}

A 6.4 magnitude earthquake hit Pidie Jaya Regency, province of Aceh in Sumatra Island, Indonesia, on Wednesday 7 December 2016. This event resulting in 104 people died and others 395 injured. Rapid response and coordination of medical teams incorporated in the "Indonesian Medical Team United for Pidie Jaya" came to provide quick and precise medical care. So, in less than seven days, all the victims from its region had been properly treated. The total surgical procedure was 123 patients. After six months follow up, four patients have the infection, and one person undergoes re-surgery. (Pomonis A, 2019).

\subsection{Lombok Earthquake}

A series of earthquakes have struck off cities and regencies in Lombok Island, West Nusa Tenggara (NTB) since 29 July 2018; i.e., with the strongest shocks recorded M 7.0 (5 Aug), M 6.4 (29 Jul), and M 6.2 (9 Aug). Although the tremors were also felt in the neighboring province of Bali, only NTB Province declared emergency response status. The series causing 436 people died, 783 people with severe injury and 570 people with mild injury. (International federation, 2018)

\subsection{Palu Earthquake}

The 7.7 magnitude earthquake shock Donggala district and also affected Palu city and Parigi Mountong regency. A tsunami hit Palu City; Central Sulawesi followed by liquefaction in Palu, South Palu, and Sigi district on 28 September 2018. The disaster causing 2657 people died, 4471 people with severe injury and 87,835 people with a mild injury. The medical emergency response team was dispatched from local to international to relieving the devastating situation. A total of 386 medical teams with 3244 members actively participated in emergency response period. (Wekke et al, 2019)

\section{Result and Discussion}

According to the reports, the earthquake had an impact on most of the hospitals and clinics, including patients, equipment, and buildings which varies from mild to severe. The disaster plans established by most of the hospitals could not work well in this case due to a large-scale disaster that had not been anticipated. The panic state of local governments, causing the systematic coordination of medical assistance could not be initiated during the 
days immediately after the earthquake. In the beginning, many medical teams rushed into evacuation centres that lacked proper health care delivery systems and started temporary clinics.

These disasters were received full attention from the government. The local society was also not standing still. (Mileti D, 1996) The society actively participates in taking part and cooperating per their abilities in post-disaster response and recovery. (Richard et al, 2012) Volunteers, who were known to be medical personnel and doctors, also came from various places. The next day after the disaster, helps began to arrive, but not massively accepted. This situation happened because almost all vital sectors - one of which was transportation - were badly damaged by earthquake shocks. In the following time, the local health authority, medical association, and other related support in each area took the initiative to coordinate meetings with external medical teams once every few days. The meeting's purpose is to exchange information about health needs, the progress of relief work, and various other problems related to health system support.3 The integration of data and information has made our society massively connected. Through Facebook, Twitter, and Google Maps, people could participate in disaster management more conventionally without having to be directly involved. Freely and measurably, the use of social media could be a place to produce information related to data on disaster victims and damage in various sectors. (Whittaker J, 2015)

\section{Conclusion}

The number of deaths accumulated rapidly in several days following the disaster. Like many other earthquakes, entrapment within collapsed houses caused most of the deaths. The volunteers seemed endlessly trying to find and evacuate victims who could still be saved. Victims with minor injuries at the initial stage would be treated at a local hospital, although with minimal conditions because suffered considerable damage but some rooms could still be used for the light treatment process. As for victims with quite severe injuries, they would immediately be flown to other hospitals in a safe region. The health system, condition, and needs of evacuees changed over time after the impact. For a few days following the earthquake, many cases of moderate and severe injuries were reported and referred to functioning hospitals either in the local region or to another region. The changes in the health problems of the outpatients in evacuation centers one week and one month after the earthquake. As evacuees stayed in outdoors environments without heat or sufficient blankets, acute respiratory infections, especially influenza, became epidemic.

Even though disaster-related morbidity and mortality are difficult to define precisely. The physical and mental stress due to the quake and adverse situations in its aftermath may have correlated to increased incidence of particular diseases and worsened conditions related to chronic diseases. 3 The acceleration of disaster recovery continued to be intensified, particularly in meeting the basic needs of the refugees, medical services, basic infrastructure improvements, and normalization of people's lives.

\section{References}

Adinew, M . (2019). Effect of Climate Change on Agricultural Output Growth in Ethiopia: CoIntegration and Vector Error Correction Model Analysis. Budapest International Research in Exact Sciences (BirEx) Journal. p. 132-143

International federation of Red Cross and Red Crescent Societies. (2018) Emergency Plan of Action ( EPoA ) Indonesia : Lombok Earthquake.

International Federation of Red Cross and Red Crescent Societies. (2017). Emergency Plan of Action ( EPoA ) Indonesia : Aceh Earthquake. 
Kementerian Kesehatan Republik Indonesia. (2018). Penanganan dampak kesehatan bencana gempa bumi dan tsunami Sulawesi Tengah.

Kunii O, Akagi M, Kita E. (1995). The Medical and Public Health Response to the Great Hanshin-Awaji Earthquake in Japan : A Case Study in Disaster Planning.;2(4).

Mileti D, Noji E. (1999). Disasters by Design: A Reassessment of Natural Hazards in the United States. The National Academies Press.

National Agency for Disaster Management (BNPB) Indonesia. (2009). National Disaster Management Plan 2010-2014.

Pomonis A, Daniell J, Gunasekera R, Schaefer A. (2019). The 2018 Lombok and Palu , Indonesia, earthquakes : Loss data uncertainties, cascades and implications. In: EGU

Priester L De. (2016) Emergency and Disaster Reports An approach to the profile of disaster risk of Indonesia.

Pusat Krisis Kesehatan. (2017). Buku Tinjauan Penanggulangan Krisis Kesehatan Tahun. Kementerian Kesehatan Republik Indonesia.

Pusat Krisis Kesehatan. (2018). Kondisi Puskesmas dan Rumah Sakit di Sulteng. General Assembly. p. 18566.

Richard Eiser J, Bostrom A, Burton I, Johnston DM, McClure J, Paton D, et al. (2012). Risk interpretation and action: A conceptual framework for responses to natural hazards. Int $\mathbf{J}$ Disaster Risk Reduct.1(1):5-16.

Wekke IS, Sabara Z, Samad MA, Yani A, Umam R,. (2019). Palu MU. Earthquake, Tsunami, and Society Cooperation: Early Findings in Palu Post of Indonesia Disaster. In: International Conference on Challenges and Opportunities of Sustainable Environmental Development (ICCOSED).

Whittaker J, McLennan B, Handmer J. (2015). A review of informal volunteerism in emergencies and disasters: Definition, opportunities and challenges. Int J Disaster Risk Reduct.;13:358-68. 